\title{
The World Upside-Down: The Carnivalesque Studio in Entre visillos
}

\author{
Stuart G. A. Sones \\ Faculty Mentors: Dr. Reyes Vila-Belda, Department of Spanish and Portuguese, Indiana University \\ Bloomington, Dr. Jane E. Goodman, Department of Anthropology, Indiana University Bloomington
}

\begin{abstract}
Carmen Martín Gaite's Entre visillos follows the experiences of several young, middle-class women living under the dictatorship of the Spanish general, Francisco Franco, during the 1950s. This neorealist account poignantly portrays the conservative confines of both traditional Spanish culture and fascist dictatorship in which these women lived. Despite these draconian conditions, Martín Gaite illustrates the bohemian party at the top-floor studio apartment of Yoni, an eccentric artist, as a space where women find agency in suspending their social responsibilities and gendered expectations. This essay, addressing this overlooked scene, examines how Martín Gaite applies place, setting, and temporality to define the characters' behavior and adherence, or nonadherence, to moral expectations under Francisco Franco's authoritarian, reactionary rule. Specifically, I analyze the spatial conditions for liminal anomie, the temporal dissolution and subversion of norms, in the novel. Through an approximation of Mikhail Bakhtin's carnivalesque and Michel de Certeau's theory of everyday resistance, I argue that the characters employ tactics of resistance against hegemonic social conventions to establish the studio soirée as a carnivalesque space. The private garret, far from the surveillance of the State, the pastoral power of the Church, and gossip of the family, acts as a safe haven for anomie, the expression of veiled attitudes, and the reimagination of Spanish identity during the epoch. By studying how the characters stray from societal mores through their paradoxical interpersonal relations, absurd values, and parodical behavior, it becomes clear that the studio is a unique, free space for contesting conventions of modesty and patriarchy under the Spanish dictatorship. The inclusion of themes of promiscuity, infidelity, and immodesty in the novel further reveals that Entre visillos itself is a carnivalesque work that reimagines the values, norms, and conscience of Spanish society.
\end{abstract}

\section{KEYWORDS: gender studies, Francoism, carnivalesque, Entre visillos, Spanish literature}

\section{INTRODUCTION}

$\mathrm{Y}$ ves Montand blasts from the record player, an engaged woman reconsiders finishing her secondary studies, and an Englishman tap dances, belting bulerías. These images seem surprising given the reactionary, authoritarian environment of General Francisco Franco's regime in post-Civil-War Spain. French music, women seeking independence through education, and the satirical display of folkloric Spanish culture in a middle-class studio apartment all seem to hint at the unraveling of borders, conservative morality, and traditional gender roles. Carmen Martín Gaite's Entre visillos (Between Lace Curtains) reflects on the mundane, quotidian lives of several young, middle-class women inhibited by the strict regime in a small Spanish city during the 1950 s $^{1}$. In doing so, Martín Gaite stealthily critiques the suffocating moral conventions young women must bear, and insinuates, to the state's despair, women's resistance to dominant ideologies in their desire to escape the limited worldview of their marginalization behind window curtains.

Through a neorealist, almost ethnographic, account, Martín Gaite underscores the frivolous boredom and repressive emptiness that dominated the lives of three sisters and their friends, exposing the dictatorial and societal repression that enveloped the city's social milieu. Centering on the lives of adolescents straddling the freedoms of childhood and expectations of womanhood, the heart of Martín Gaite's Bildungsroman, as Lynn K. Talbot describes, is the "development of the adolescent and 'the quest of the youthful self for identity'."2 Entre visillos follows the tensions that arise when Pablo Klein arrives to the provincial city to teach German at the local institute. Pablo's critical perspective, progressive teaching pedagogy, and distinctive worldview as a foreigner, whose only connections to the city are his childhood memories, clash with the hegemonic conformity of the community. Nuria Cruz-Cámara posits that Pablo

\footnotetext{
1 Carmen Martín Gaite, Entre visillos (Barcelona: Austral, 2012).

2 Lynn K. Talbot, "Female Archetypes in Carmen Martín Gaite's Entre visillos," Anales
} de La Literatura Española Contemporánea 12, no. 1/2 (1987): 82. inspires several women to break the mold: "Pablo sirve como una válvula de escape para los habitantes de ese universo cerrado, y en él varios personajes desahogarán sus frustraciones y sus anhelos de liberación y huida.”3 Pablo’s influence incites several young women to confront repressed external and internal conflicts with society and self. Although Pablo's rebellious inspiration makes these women conscious of their marginalization, inculcated social norms and internalized notions of submissive femininity continue to greatly limit these women's agency in achieving any level of independence. For example, sixteen-year-old Natalia, the youngest of three sisters and a student of Pablo's, aspires to continue her education after secondary school, but she fears approaching her father, a representation of the patriarchy, about the issue. Similarly, Elvira Domínguez, a daydreamer infatuated with Pablo, suffers from a "psychological self-entrapment" stemming from internalized repressive practices, evident in how she sexually fantasizes about Pablo, yet condemns him for attempting to satisfy her fantasies. ${ }^{4}$ These cases exemplify the complex ways in which the ingrained habitus ${ }^{5}$ of dominant, patriarchal ideology stifles women's individuality and independence in the novel.

Despite such homogenizing forces in the city, the reader peeks through the curtains of the studio apartment-analogous to how the protagonist Natalia peers out from behind the lace-to find that young women begin to tear Spain's social fabric. Several women (among them, Gertru, Natalia's friend; Julia, Natalia's older sister; and Mercedes, the eldest sister) actualize their yearning for liberation in the studio scene. In this scene Yoni, the eclectic, progressive sculptor and son of the wealthy owners of the Gran Hotel, hosts a soirée

\footnotetext{
${ }^{3}$ Nuria Cruz-Cámara, “'Chicas raras' en dos novelas de Carmen Martín Gaite y Carmen Laforet," Hispanófila, no. 139 (2003): 99.

${ }^{4}$ Marsha S. Collins, "Inscribing the Space of Female Identity in Carmen Martín Gaite's Entre visillos,” Symposium 51, no. 2 (1997): 72

5 Pierre Bourdieu, Outline of a Theory of Practice (Cambridge: Cambridge University Press, 1977). Habitus refers to the totality of structured and ingrained habits, dispositions, and unconscious schemes of thought that are socialized in a given society.
} 
in his studio apartment, threatening imposed societal conventions. At his party, men and women intermingle and drink freely, foreign music invades autarkic Spain, and an Englishman comically chants las bulerías despite the conservative and politically isolated environment. The backdrop of absurd, rambunctious partying sets the scene for young women to reenvision their marginalized status.

The top-floor studio apartment of the hotel, defined by its spatial and temporal context, forges a free space where liminal anomie engulfs the sisters and their friends. Anomie arises from a conflict of belief systems that causes the disintegration of the relationship between individuals and society, thus eroding community conventions. Holding liberal beliefs on gender norms and freedoms, the middle-class party-goers clash with moral conservatism and authoritarian rule, engendering the temporary dissolution and subversion of standard norms in the studio. As such, both men and women take advantage of the studio's liminal normlessness to express themselves freely, giving them a taste of different possibilities and the potential for palpable, long-lasting nonadherence to social mores. In this state of anomie, the characters experiment with distinct lifestyles, invert social norms, and imagine new social identities. As one of the guests, Federico, announces, "aquí es el único sitio donde se pasa bien." 6 The bohemian attic of Yoni's studio during the party is a carnivalesque space (carnivalesque, as Bakhtin defined, is the world upside-down where social roles and mores are reversed) in which men escape the banality of provincial life and young women are free to resist repression imposed by hegemonic Francoist society.

From an approximation of Mikhail Bakhtin's carnivalesque theories, I examine Yoni's garret as a carnivalesque space that serves as a safe haven for a desired, liminal anomie in which the defiance of traditional society is possible. Applying Michel de Certeau's theories of space and everyday resistance, I elaborate that the escape to the studio and the utilization of the anomic vacuum to subvert norms serve as tactics of resistance that comprise everyday defiance to conservative society and fascism. While men flirt, enjoy foreign luxuries, and mock conservative politics, escaping insipid autarky, women freely conceptualize a new life for themselves in the studio. Divergent from other settings in Entre visillos, in which women are marginalized, the bohemian studio during the party converts into a space for women's agency, the expression and performance of James C. Scott's theory of hidden transcripts, and the reimagination of the Spanish conscience.

\section{FEMALES OF THE FRANCO ERA: GENDERED NORMS AND STATE POLICY}

Carmen Martín Gaite (1925-2000) was born and raised in the provincial city of Salamanca. Her own experiences and observations studying in Salamanca during the first years of the dictatorship must have inspired her novel's realistic, almost ethnographic, portrayals of women's lives during the early postwar period. An omniscient narrator, the diary entries of Natalia, and the foreign perspective of Pablo Klein all narrate the seemingly mundane drama that envelopes the city. Through these three viewpoints, the novel centers on women's role in and relationship to Spanish society, elucidating women's reaction to their cloistered bodies and minds. As a glimpse into the lived realities of the era, the reader "has the opportunity to observe, analyze, and judge women's position in society." With this logic, we may understand Martín Gaite's work as an elaborate compilation of ethnographic fieldnotes written in excruciating detail to capture the experiences of middle-class

\footnotetext{
"Martín Gaite, Entre visillos, 191

Talbot, "Female Archetypes," 80
}

women in post-civil-war Spain-ethnographic fiction. By studying Entre visillos from an anthropological lens, we may better dissect and understand the role, sentiment, and agency (or lack thereof) of young women during the dictatorship.

In this section, I shall first analyze the historical and political trends that shaped women's civil and cultural status in society and that which influenced the lifestyles of the women in this novel. Based on these patriarchal dictums, I shall analyze the literary archetypes of femininity manifested in the novel's principal characters. These developments not only shed light on the social dynamics of the novel, they also identify that the studio apartment and the behaviors that occur there have yet to receive the scholarly attention they deserve.

As a reactionary divergence to changing gender roles, a symptom of the coming of 'modernity' which 'plagued' the interwar period, Franco's coup d'état of 1936 reestablished traditional, patriarchal family norms, indiscriminately linking la mujer to la familia. ${ }^{8}$ Following the Nationalist faction's victory over the Republicans in the bloody civil war (1936-1939), according to Helen Graham, the patriarchal family would become the foundation of Francoist social structure, "representing the corporate order of the state in microcosm." "Policies that deindividualized women were emblematically advanced in the Ley de bases of 1938 which "freed" married, middle-class women from public work. ${ }^{10}$ Legislation, then, forced middle-class women into domestic roles, sheltered behind the mirador (windowed balcony) of the traditional provincial home. Domestic roles not only mandated women to reproduce life for the patria, but also reproduce ideology: women oversaw "correct ideological reproduction via the socialization of children in the home-the goal here being the imposition of social hierarchy." 11

The trope of motherly authority figures who embody and enforce patriarchy in the household is nothing new in Spanish literary history. A famous example is Bernarda from Federico García Lorca's La casa de Bernarda Alba. ${ }^{12}$ Written before the 1936 coup, the themes of family, gossip, and repression presented in the play underline the imbedded history of women as agents of female repression in Spain's sociocultural and literary history. What proves to be distinctive of the post-civil war era, however, was the Church and State's patriarchal restoration campaign which reached into the core of family life. State and religious institutions worked to shape young women into docile subjects and indoctrinate women in state cult morality, priming them for marriage and domestic life.

The Catholic Church and State maintained a symbiotic relationship since the early years of Franco's regime. While the State politically empowered the Church, the Church gave religious legitimacy to Franco's brand of nationalism and helped to systematically facilitate the homogenization of Spanish culture in the 1950s. The indistinguishable realms of the religious and the political in the relationship between these two institutions came to be known as National Catholicism. The 1953 Concordat between the Vatican and Spain gave far-reaching authority to the Church in Spanish society, ${ }^{13}$ granting the Catholic Church hegemony over public and private life. Among the privileges of the Church were "the exclusive right to pursue missionary activities and to teach religion (a compulsory subject at all educational levels), to financial

\footnotetext{
8 Helen Graham, "Gender and the State: Women in the 1940s," in Spanish Cultural Studies: An Introduction: The Struggle for Modernity, ed. Helen Graham and Jo Labanyi (Oxford: Oxford University Press, 1995), 184.

9 Graham, "Gender and the State," 184.

${ }^{10}$ Graham, 184

11 Graham, 187.

${ }^{12}$ Federico García Lorca, Allen Josephs, and Juan Caballero, La Casa de Bernarda Alba, 24th ed. (Madrid: Cátedra, 1997).

${ }^{3}$ Cathelijne de Busser, "Church-state Relations in Spain: Variations on a NationalCatholic Theme?” GeoJournal 67, no. 4 (2006): 286
} 
support from the state and access to all forms of communication."14 The Church under Francoism exerted a form of Foucauldian "pastoral power" that transposed the microcosm of a father's care over his family onto the supervision and support of, and moral governing over, the individual, state subjects, and society. ${ }^{15}$ As Catholic principles and morality became inscribed in Spanish law, the Church played a major role in everyday life on a more personal level. Gender-segregated Catholic schools were the norm of the era and the cathedral's central location in Martín Gaite's novel emphasizes its importance to the community-so much so that it seems as if every winding street in the novel leads back to it. The Church's ideology greatly affects the women in Entre visillos. Marsha S. Collins outlines that the Catholic confessional in the novel in particular espoused a "rhetoric and ritual of shame and guilt [to] drive out the demons of deviant female thought and behavior." 16 It is National Catholicism's enforcement of cult morality that defines the practices of the Church and State as pastoral power seeking to prescribe, support, and productively shape modest and pious lifestyles among their subjects.

Another ideological institution founded on similar principles was the Sección Femenina of the Falange party, headed by Pilar Primo de Rivera, sister of the founder of the Falange party, José Primo de Rivera. This state social organization ordered that any single or widowed women who sought higher education or employment would have to complete its Servicio Social, a sixmonth, five-hundred-hour program that equipped women with skills in domestic work among other everyday activities. ${ }^{17}$ Soledad Fox notes that "From 1945 on, women were legally required to complete the program, which was aimed at morally purifying them and ensuring their futures as ideal Spanish mothers." ${ }^{18}$ Although women of the era might have found leisure and community in the social service, Fox argues that the program nevertheless had undeniable brainwashing potential. Since "those already ensnared [in gendered ideology] work to reduce other females to the same state," 19 once indoctrinated into state prescribed domestic norms by the Sección Femenina, women return home incarnating the patriarchal ideology of the state and inculcate it among their children. Thus, the state deploys women themselves as agents of women's repression.

Conscious of these sociopolitical orders, Martín Gaite portrays la tía Concha, Natalia's aunt who lives with the family following her mother's death, and Natalia's older sisters as arbiters of morality and order in Entre visillos. Natalia explains to Pablo Klein that la tía Concha "era la que mandaba en todos y se había empeñado en civilizarla a ella." ${ }^{20}$ At home, la tía protects the chastity and honor of the family. She conducts the behavior and rhythm of the household. For example, la tía condemns Natalia for her 'unwomanly' behavior: "'no sabes ni saludar."'21 Furthermore, Natalia's aunt primes the sisters for wedded life. In her diary, Natalia writes that "la tía Concha nos quiere convertir en unas estúpidas, que sólo nos educa para tener un novio rico, y que seamos lo más retrasadas posible en todo, que no sepamos nada ni nos alegremos con nada."22 Natalia's entry not only underscores how women serve as agents

\footnotetext{
${ }^{4}$ Busser, 286.

${ }^{5}$ Michel Foucault, “Governmentality,” in Michel Foucault, Power, ed. James Faubion (New York: New Press), 222.

${ }^{16}$ Collins, "Inscribing the Space of Female Identity."

${ }^{7}$ Soledad Fox, "Cellophane Girls: Feminine Models in Entre visillos and Usos amorosos de la postguerra española," in Approaches to teaching the works of Carmen Martín Gaite, ed. Joan L. Brown (New York: The Modern Language Association of America, 2013).

${ }^{18}$ Soledad Fox, "Cellophane Girls."

${ }^{19}$ Talbot, "Female Archetypes," 83.

${ }^{20}$ Martín Gaite, Entre visillos, 240.

${ }^{11}$ Martín Gaite, 244

22 Martín Gaite, 254
}

for socializing women into docile beings, uncritical of marginalized womanhood in a way that maintains social order, but also Natalia's resilience to such repressing standards.

Moreover, Mercedes, the eldest sister, serves a similar role in maintaining patriarchal order. Mercedes belittles Julia for loving an unorthodox playwright and Natalia for her refusal to wear long dresses, a symbol of modesty. ${ }^{23}$ These women, unconscious of the hegemonic ideology they reproduce, work to reinforce the sociopolitical gender order and norms, coercively defining idealized womanhood.

In Francoist Spain, idealized womanhood would come to represent submission, piety, and self-denial. ${ }^{24}$ Adolescent women in Martín Gaite's novel, grappling with their liminal status between childhood and womanhood, both embody and defy idealized notions of femininity. Talbot brilliantly analyzes Entre visillos from a literary archetypal framework, highlighting how recurring images and symbols in feminine works of fiction represent the marginalization of women in patriarchal society. ${ }^{25}$ Talbot defines two primary archetypes among the women. First is the "growing up-grotesque" archetype which reflects how societal pressure limits women's development of independence and intellect. ${ }^{26}$ Rather than having agency to make pivotal life decisions, society determines their seemingly meaningless domestic livelihoods. This archetype is exemplified in how customs thwart young women's dreams as they must negotiate between their personal desires and what is deemed best for the family and society. The sixteen-year-old protagonist, Natalia, the youngest of the three sisters, is reluctant to submit to traditional female roles and identities, which, according to Talbot, "reflects her struggle for authentic selfhood." 27 Not only does Natalia refuse to behave and dress 'properly,' she also aspires toward a university degree in an environment that dismisses women's education. Despite Pablo Klein's encouragement, Natalia fears approaching her father about continuing her education. At the end of the novel, the audience is left wondering whether she will achieve her aspirations.

Similar to Natalia, Elvira Domínguez struggles for authentic selfhood. Elvira is a creative artist, yet ideas of proper womanhood, as well as her expected mourning after her father's death, pressure her to keep her art hidden. Elvira, however, is cognizant of patriarchy's restrictions. Over the course of the novel, she laments the suffocating, provincial city life. Elvira's love affair with Pablo Klein represents her efforts to escape the confines of traditional wedded life. Although she spends most days shut inside her bedroom reading, she never stops daydreaming of escape: "'me gustaría irme lejos, hacer un viaje largo que durase mucho. Escapar," she confesses to Pablo. ${ }^{28}$

Natalia and Elvira reflect what Nuria Cruz-Cámara terms "chicas raras," or strange girls ${ }^{29}$ Chicas raras are those who question the feminine paradigm of their society. As Cruz-Cámara notes, the novel evokes the narrative structure of Bildungsroman, a narrative of individual development during formative years, the borderlands between the liberty of adolescence and the imminent responsibilities and expectations of womanhood. This timeframe is when "se empieza a manifestar su rareza respecto a los modelos imperantes en la Sociedad en la que están creciendo." 30 The liminality of adolescence forces women to question gender roles and confront ideal femininity. Chicas raras prefer to die than submit to the destiny of being "una mujer resignada y razonable"-a resigned and reasonable woman. ${ }^{31}$

\footnotetext{
23 Talbot, "Female Archetypes," 83.

${ }^{24}$ Graham, "Gender and the State," 184.

25 Talbot, "Female Archetypes," 81.

${ }^{6}$ Talbot, 82.

${ }^{27}$ Talbot, 84

${ }^{28}$ Martín Gaite, Entre visillos, 126.

${ }^{29}$ Cruz-Cámara, "Chicas raras,” 97-110.

${ }^{30}$ Cruz-Cámara, 98

${ }^{31}$ Cruz Cámara, 99.
} 
Although Natalia and Elvira rebel against gender norms in their everyday life, they rely on men to provide this escape. Natalia leans on Pablo to encourage her education. Elvira marries Emilio who promises that they will escape the city, freeing Elvira to pursue her art and Emilio to pursue his studies. While Catherine G. Bellver posits that this reliance on men does not constitute the full actualization of the self against the grains of Spanish norms, ${ }^{32}$ I believe this avenue provides women the negative agency-agency that emphasizes working with and maneuvering within social structures rather than overcoming them-to navigate the frameworks of patriarchal society. Nevertheless, this reliance on men constructs a major distinction between the two chicas raras. On one hand, Natalia turns to Pablo to buttress her educational pursuits, which underlines her persistent rejection of traditional feminine identities. On the other hand, although Emilio speaks about "la libertad de la mujer [y] de su proyección social," 33 he nevertheless breaks his promise, hindering Elvira from achieving her dreams by keeping her in the city. Elvira retires her dreams of escaping the city by marrying Emilio, assimilating to and internalizing the gendered mores of married provincial life.

Contrary to the rebellious characters of Natalia and Elvira, Natalia's sisters and friends, reflecting women's traditional socialization, succumb to the reproduction of symbolic violence, ${ }^{34}$ gender roles, and social hierarchy in Francoist Spain. While this is partially true of these characters, it must be qualified in the case of the bohemian studio scene. According to Collins, "some of the women, like Natalia's sisters Mercedes and Julia, as well as Tali's [Natalia] best friend Gertru, seem predisposed or preconditioned to accept social positions of dull respectability, whether as virtuous spinsters or obedient wives." 35 Gertru dropped out of secondary school; Ángel, her fiancée, forced her to abandon her studies to tend to the home. Julia, the middle sister, must balance her independence and obligations to her family and father. Although her boyfriend, Miguel, is a playwright in Madrid, social norms prevent her from achieving her dream of escaping the small provincial city. Julia's yearning to marry an eccentric man provides another example of how women attempt to escape traditional lives. Finally, Mercedes, the eldest sister, the most conservative and norm-abiding of the three, takes it upon herself to enforce patriarchal norms among the sisters. Martín Gaite's portrayal of these women's lives masks the social commentary that underlies the drama of the conservative city. This social commentary, particularly in the studio apartment scene, qualifies and challenges the assumed submissive characteristics of these women.

From the analysis of the "growing up-grotesque" archetype, we discover how "Martín Gaite exposes the repressiveness of patriarchal control, yet she also suggests the possibilities of change through the actions of defiant women." 36 In painting women as chicas raras, Martín Gaite constructs a reimagined feminine woman in opposition to Francoist femininity. The rebellious aspirations of education and unorthodox married life outside the city suggest the reworking of female agency under the regime and contrast with the feminine archetype that maintains the social order of fascist

\footnotetext{
${ }^{32}$ Catherine G. Bellver, "Gendered Spaces: Boundaries and Border Crossings in Entre visillos," in Carmen Martín Gaite: El cuento de nunca acabar/Never-ending Story: (apuntes sobre la narración, el amor, y la mentira), ed. Kathleen M. Glenn and Lissette Rolón-Collazo (Boulder: Society of Spanish and Spanish-American Studies, 2003), 34.

${ }^{3}$ Martín Gaite, Entre visillos, 273

${ }^{34}$ Pierre Bourdieu and Loïc J. D. Wacquant, An Invitation to Reflexive Sociology (Cambridge: Polity Press, 1992). Symbolic violence refers to the unconscious acceptance of one's constructed image of the self in society, and thus, the tacit acceptance of power stratification.

${ }^{35}$ Collins, "Inscribing the Space of Female Identity."

${ }^{36}$ Talbot, "Female Archetypes," 81
}

Spain. Prior literature on the subject of gender in Entre visillos, however, stereotypically frames Mercedes, Julia, and Gertru as submissive subjects of patriarchal society, overemphasizing a static, repressed image of these young women. This image does not account for the irregular behaviors, self-realizations, and the redefinition of femininity that incubate at the studio apartment party. Since Natalia and Elvira were not present at the party, the objective of this paper is to reconsider these women according to their actions during the bohemian party scene and reposition them as agents in reconstructing Spanish femininity of the era. The studio, I contend, is the liminal space, the exception to the rule, where conservative women are permitted to rethink gender and fascist society itself. The party must be analyzed as a carnivalesque space of subversion, hedonism, and resistance.

\section{SUFFOCATION AND ESCAPE: THE GENDERED SYMBOLISM AND POLITICS OF SPACE}

Before diving into the studio apartment as a social and spatial exception, we must first establish an understanding of the rule in traditional Spanish society and the works of Martín Gaite. The relationship between space and gender in the works of Martín Gaite has received great scholarly attention during the past century of feminist literary criticism (see Bellver 2003; Collins 1997; Ochoa 2011). The most prominent inquiry has been into women's relation to the juxtaposition of interior and exterior spaces, domesticity and the unfamiliar. According to Bellver, women in Spain have historically been excluded from public space and life, a practice steeped in medieval Christian morality and the veneer of remnant Islamic perspectives on gender. ${ }^{37}$ Bellver highlights several objects in the novel that symbolize the division between public space (i.e. the domain of men) and private space (the domain of women): women are hidden behind symbols like veils, gowns, curtains, and fans. ${ }^{38}$ Martín Gaite inscribes many of these symbols in the text, most predominantly in the novel's titular lace curtains that shield women from the streets and immodesty.

The strict management of space in Spanish society and the novel prove to be a strategy of maintaining gendered hierarchy. The divisions between male and female life, embodied in public and private spatial boundaries, "promote the desired outcome, with regard to women, of inferior social status, ignorance, and passivity." 39 The interior order of provincial life excludes women from public discourse, further marginalizing their subaltern voices and further articulating the regime's dominant ideology in microcosm. Enclosure, a major motif in the imagery of the novel, "reinforces the impression of a restrictive society, closed in its configuration and structure, that hinders those who live in it from achieving their true aspirations." 40 Throughout the novel, Natalia, Julia, and Mercedes often allude to being suffocated and trapped in their home. Natalia, for example, complains to her father that la tía keeps them "encerradas como el buen paño que se vende en el arca." ${ }^{11}$ The women must convince their aunt to go out during the city fair at the beginning of the novel. Once permitted to leave, they are sanctioned by strict curfews. The suffocating enclosure of closed space is a clandestine metaphors for the female condition that Martín Gaite embeds into the otherwise monotonous narrative of petty, provincial drama.

\footnotetext{
Bellver, "Gendered Spaces," 39.

${ }^{38}$ Bellver, 39.

39 Bellver, 35

${ }^{40}$ Talbot, "Female Archetypes," 84.

${ }^{41}$ Martín Gaite, Entre visillos, 254.
} 
In spite of the restrictions of movement, the imagery of windows provide hope for women's liberation and Martín Gaite's critique of oppressive state policies and patriarchal social structures. Marín Gaite's argues in her work, Desde la ventana, that in Spanish literature "La ventana es el punto de enfoque, pero también el punto de partida." ${ }^{\prime 2}$ Although the multitude of references to windows in Spanish literature point to the stuffy reality of life behind glass, these references may also hint at the possibility for departure, literally opening windows and transcending domesticity. The mirador, or windowed balcony of the middle-class provincial home, emblematically symbolizes the threshold between the space assigned to women and the impermissible, purity and impurity. ${ }^{43}$ Sheltered, gazing out of the mirador was the female condition under the regime. While the term ventanera (the window-gazing state) pejoratively denoted women's rejection of her proper place at home in Siglo de Oro literature (c. 1492-1681), Martín Gaite 'flips the script' in a feminist approach to Spanish culture. ${ }^{44}$ Debra J. Ochoa posits that Martín Gaite inverted and reclaimed this condition to reflect the positive notion of a woman's desire to escape the home, her marginalization, and the confines of patriarchal society..$^{45}$ If a woman were to act upon her desire to escape her bounded existence at the window's threshold, however, physically leaving the home and entering the domain of the streets, a woman may encounter much of the same social repression from society at large.

The streets are just as suffocating as closed spaces in the novel. Narrow streets are stale corridors that seem to lead to the cathedral, a constant reminder of expected piety and the institutionalization of the Church in society. The public school, as Pablo notices, looks as if it were military barracks. ${ }^{46}$ Not only are public spaces unbearably confining, they are also ruled by the supervision of men and community members who serve similar roles as the superintending, conservative family. The cultural and literary notion of el qué dirán (what they will say), the community gossip that stains the relationship between women and society, dominates the streets and public venues throughout the novel. For example, when Pablo invites Natalia for coffee at a local café, she fears that her father will see her with a stranger. ${ }^{47}$ Although their voices are not valued, women's actions and bodies receive much attention in the conservative city. A woman is held responsible for upholding the honor of her family when in public and therefore may potentially tarnish her family's reputation by stepping out of line. While Elvira crosses the central plaza with Pablo and Yoni, Yoni is quick to caution Elvira that "si la veían acompañada de dos hombres que no eran Emilio [her future husband], y en pleno luto, que la iban a criticar." 48 Yoni's words resonate with the tell-tale forces of el que dirán that consume public space for women. El que dirán holds a Foucauldian sense of self-regulatory social pressure that disciplines women into abiding by social norms.

The breaking of norms in public space provokes harsh consequences in Entre visillos. Rosa is an entertainer who performs at the local Casino, and therefore is considered a "liberated" woman. ${ }^{49}$ Although the Casino may seem like a place for recreation and relaxation, Martín Gaite portrays the Casino as enshrouded in the same social pressure and gossip as any other location in the novel. Rosa's public performance leaves her vulnerable to the

\footnotetext{
${ }^{42}$ Carmen Martín Gaite, Desde la ventana (Madrid: Espasa Calpe, 1999), 36-37.

${ }^{43}$ Bellver, "Gendered Spaces," 39.

${ }^{44}$ Debra J. Ochoa, "Martín Gaite's Visión de Nueva York: Collages of Public and Private

Space," in Beyond the Back Room: Perspectives on Carmen Martín Gaite, ed. Marian Womack and Jennifer Wood (Oxford: Peter Lang, 2011), 95.

${ }^{45}$ Ochoa, 95

${ }^{46}$ Talbot, "Female Archetypes," 84

${ }^{47}$ Martín Gaite, Entre visillos, 239.

${ }^{48}$ Martín Gaite, 275.

${ }^{49}$ Bellver, "Gendered Spaces," 43.
}

young women's scrutiny, who shun her for what they perceive as prostitution. The foreigner Pablo Klein, on the other hand, is the only character who associates with her in the novel. In a similar case, Gertru's sister marries a man from a different social class, provoking her parents' disdain. Shunned from her family, Gertru's sister is forced to move outside the city, outside the realm of community supervision. These examples showcase how Martín Gaite applies space to reflect gender, hierarchy, and the social strictures women must follow in Francoist Spain.

The symbolism of nature in Entre visillos, evident in Gertru's sister move to the countryside, marks what Talbot analyzes as the second primary archetype in the novel: the "green-world" archetype. This literary archetype associates young women with nature, the landscape where they find an escape from the real world. ${ }^{50}$ Far from the critical eye of the city, nature is a space for self-reflection and the suspension from societal norms. Natalia finds respite exploring the countryside outside of the city. Pablo Klein takes his German class to the riverbank where the young girls feel more able to learn and think in the free environment. Furthermore, Elvira feels more comfortable expressing her feelings to Pablo while laying by the river. While nature is an escape for Natalia and her classmates and a refuge for opening up the heart for Elvira, I posit that there are other settings in the novel, such as the studio apartment, which also serve as safe havens from the monotony and repression of the small city.

Despite the confinement of both private and public space, Entre visillos highlights how women reclaim these areas in the novel. Marian Womack notes that women redefine feminine selfhood from their positions behind lace curtains: "Martín Gaite's intention... is to regain these spaces for the feminine freedom and creativity." ${ }^{1}$ The protagonist, Natalia, in particular, skillfully adopts conservative spaces for her own personal development. Although closely monitored by her family who "casi siempre están hablando de mí," 52 she studies in her room or salon, forging a space for herself to transcend the limited consciousness of domestic life to pursue greater ideas and movements. Reclaiming individuality through negotiating space also takes place outside of the home. Bellver argues that Natalia's navigation of open, public spaces (her classes by the riverside, for example) "not only challenges the oppressiveness of provincial life, it also marks a step in her development of toward self-realization." 53 These analyses of women redefining their confinement in the novel, however, have again ignored the pivotal studio apartment scene in which, in a similar manner, women reclaim space. The studio apartment is a space where the unthinkable in Spanish society actualizes and comes to reshape the way that women conduct themselves during the remainder of the novel. If society is held to the norms that I have outlined above, then how is it that both men and women openly transgress Francoist standards without repercussion in the studio apartment? The bohemian party in the studio, then, must be analyzed as a carnivalesque space where men and women renegotiate themselves and their roles in Spanish society.

\section{CARNIVAL, POWER, \& RESISTANCE}

In analyzing the bohemian studio, it is necessary to first outline how Martín Gaite applies spatial structures to delineate the symbolic workings of self-regulatory, disciplinary powers in the small city.

\footnotetext{
${ }^{50}$ Talbot, "Female Archetypes," 82.

${ }^{1}$ Marian Womack, Introduction to Part Two: "Space / Fantasy" of Beyond the Back Room: Perspectives on Carmen Martín Gaite, ed. Marian Womack and Jennifer Wood (Oxford: Peter Lang, 2011), 102.

22 Martín Gaite, Entre visillos, 243.

53 Bellver, "Gendered Spaces," 43.
} 
Public space and private venue under the Franco regime became imbued with State ideology. The State pervades much of social life in Entre visillos, exemplified by the portrait of Franco that looms over Natalia's classroom. Collins posits that this "decidedly male voice of power reminds women of their limited place in society." 54

The regime is also symbolically evoked in greater spatial structures that the young women navigate in the novel. In her critical analysis, "Determined, Detached and Drowning: The Use of Rhetoric of Enclosure in Carmen Martín Gaite's Entre visillos," Tiffany Gagliardi describes how Francoist power and societal vigilance restrict the characters' behaviors. The cathedral's bell tower, according to Gagliardi, represents the overseeing, institutional power of the Church and State over society. The Casino's balcony symbolizes social pressure and el qué dirán in the community. Both of these elevated structures reflect Michel Foucault's analysis on the passive, self-regulating disciplinary and surveillance power of Bentham's Panopticon in Discipline and Punish. ${ }^{55}$ Since power often rests in elevated space, the two landmarks dominate the city. These high-vantage-point settings construct the power that Gagliardi analyzes as "delineated physical geography that imposes societal confinement upon the women." 56 The clock face of the cathedral's campanile resembles "un ojo gigantesco" that overlooks the city, monitoring the women's every move. ${ }^{57}$ Meanwhile, when Pablo Klein goes to the Casino, he soon discovers how uncomfortable and suffocating the space is, not because of the lack of open space, but rather because the open architectural layout allows leering eyes to peer down from the balcony: "la primera cosa que me di cuenta al entrar, fue de que no existía ningún lugar apartado, sino que todos estaban ligados entre sí por secretos lazos, al descubierto de una ronda de ojos felinos." 58 These cases highlight that the surveying eyes of the Catholic Church and Falange, intertwined with the critical gaze of a conservative community, hold a monopoly over social life in most parts of the city.

The omniscient power of societal pressure, or el qué dirán, and the pervasive, all-knowing Church and State are inscribed in the physical geography of the novel. The characters are conscious of this overreaching surveillance and act accordingly. These physical landmarks become self-regulatory, preventative forces that thwart any behaviors designated as 'inappropriate' according to Francoism. Although Gagliardi's argument brilliantly defines how power mediates life through space, she does not address the other tall structure present in the work: the top floor of the Gran Hotel, Yoni's garret. Gagliardi's theory does not account for the inversion of rigid norms during Yoni's bohemian party in chapter XII. The height of the studio loft symbolizes a clash against the bell tower (the Church and State) and the balcony of the Casino (societal pressure and el qué dirán). Marking the city's skyline in opposition to the towering cathedral, the elevated top-floor studio houses a commanding subcultural resistance to dominant ideology and power. The studio's privacy rejects the State's power of surveillance, allowing the characters to act as they please. In this space, sedition is possible.

Practices of Everyday Life by Michel de Certeau is an interesting line of inquiry into the theories of resistance. De Certeau investigates the quotidian, spontaneous, and opportunistic tactics that individuals utilize to undermine the strategies that organized power

\footnotetext{
${ }^{4}$ Collins, "Inscribing the Space of Female Identity." 74

${ }^{5}$ Michel Foucault, Discipline \& Punish: The Birth of the Prison, trans. Alan Sheridan (New York: Vintage Books, 1995), 200-201.

${ }^{56}$ Tiffany D. Gagliardi, "Determined, Detached and Drowning: The Use of Rhetoric of Enclosure in Carmen Martín Gaite's Entre visillos,” Letras Peninsulares 16, no. 3 (2003): 435

Martín Gaite, Entre visillos, 61.

${ }^{58}$ Martín Gaite., 132
}

impose in maintaining sociopolitical order. De Certeau argues that although citizens subject to imposed state order cannot escape such hegemonic domination, they can "continually manipulate events within the system in order to precipitate 'fragmentary and fragile victories of the weak." 59 In employing these tactics, subordinate groups take advantage of circumstances to subvert the authoritarian strategies of the State. ${ }^{60}$ These groups construct alternative spaces to express progressive ideas and 'unacceptable' behaviors. Within these spaces, divergent consciences form as a mode of defiance against the State.

De Certeau's theory of everyday resistance is particularly apt for analyzing the studio scene in Entre visillos. The characters' actions reflect minute acts of defiance which forge and construct the carnivalesque space. Frustrated by family rules and omniscient state power, the characters defiantly escape to the carnivalesque soirée in Yoni's garret. When Federico invites Julia to the party, "le daban ganas de escapar" from her aunt's surveillance, suffocating enclosure, and the imposed emptiness of Francoist society. ${ }^{61}$ Furthermore, behaviors at the party reflect the state of liminal anomie, the vulgarization of the regime, and the reimagination of the Spanish identity that constitute minor modes of resistance against hegemonic cultural norms.

Yoni's studio, molded by acts of everyday resistance, is the world upside-down, a social milieu that contrasts sharply with the norms that permeate the character's lives in the non-carnivalesque world. In Problems of Dostoevsky's Poetics, Mikhail Bakhtin develops his literary theory of the carnivalesque from the medieval fair, originally celebrated by Church clergy preceding Lent. Full of sacrilege and impiety, celebrating clergymen would challenge Church hierarchy and contest the truth. Thus, carnival is defined by temporal and spatial challenges to the mundane realities of stratified society. Bakhtin applies this historical understanding of carnival to several literary genres, such as the Menippean satire, which mock authority, renegotiate hierarchy, and invert social norms. This literature has the potential of altering popular imaginations and redefining social reality over time. Bakhtin referred to this transposition of the festival to literature as "the carnivalization of literature." 62 In this analysis, just as Bakhtin transposed the carnival to literature, I transpose the carnival to setting, the carnivalization of space.

Bakhtin drew his theories of the carnivalesque from the public carnival that had the potential for influencing societal norms. Such influential public occasions, however, would be unthinkable for women during the epoch of this novel, characterized by imposed modesty and family roles. Instead, the privacy of Yoni's garret provides the opportunity for women to reclaim space and allows for deviation from such societal values without social repercussions. With this in mind, it is evident that there is a dynamic symbolism in the difference between the public and private. The palpable schism between open and closed spaces showcases how gendered concepts of the public and private are embodied in spatial layouts in the novel. This schism further develops in the public and private realms of the individual, her behaviors and personal thoughts. The pressure to conform to an idealized femininity, to marry and adopt a domestic lifestyle, results in females to perform, as Collins contests, with a "front" 63 that "individuals wear in public to define or fix

\footnotetext{
Shahram Khosravi, Young and Defiant in Tehran (Pennsylvania: University of Pennsylvania Press, 2008), 2.

${ }^{0}$ Michel de Certeau, The Practice of Everyday Life, trans. Steven Rendall (Berkeley: University of California Press, 1984), 38-39.

${ }^{61}$ Martín Gaite, Entre visillos, 187

Mikhail Bakhtin, Problems of Dostoevsky's Poetics, trans. Caryl Emerson (Minneapolis: University of Minnesota Press, 1984), 122.

${ }^{63}$ Erving Goffman, The Presentation of Self in Everyday Life (New York: Doubleday, 1959).
} 
their image for others." ${ }^{64}$ I would like to expand on this sociological approach of the public performance of feminine archetypes by incorporating a more politically-oriented analysis that takes into account the power dynamics of Franco's authoritarian regime and patriarchal social structures.

Socially stratified Spanish society obliges women to put on a public face. In such stratified societies, James C. Scott discerns two modes of everyday discourse and performance, which are not necessarily in opposition to one another: public and hidden transcripts. The public transcript describes the performed interpersonal communication between the dominating groups within a society and those they dominate. ${ }^{65}$ Through maneuvered verbal and nonverbal communication, both dominant and subordinate groups put on a façade that plays into their social roles. For fear of humiliation (one of the vulnerabilities of those in power) or punishment respectively, people replicate such masquerades in a myriad of dominant/subordinate social interactions, and in doing so, constantly reproduce hierarchical power structures. On the other hand, the hidden transcript for the subordinate group describes the "off-stage" practices and sentiments that "represent a critique of power spoken behind the back of the dominant." 66 Outside the presence of authority and self-regulating power dynamics, exchanges between confidants allow for free speech, gestures, and expressions of indignation that would otherwise be self-censored. Neither the public nor the hidden transcript are more authentic to the social actor's true sentiments. Rather, both modes of expression are legitimate performances of the social actor's position in a stratified society and provide insight into the dynamics of domination on public discourse.

Francoist Spain produced fertile ground for the engenderment of hidden transcripts, since, as Scott argues, "the practices of domination and exploitation typically generate the insults and slight to human dignity that in turn foster a hidden transcript of indignation." ${ }^{67}$ As outlined previously, the dictatorship-imposed subjugation of women forced women to conform and perform a public transcript of modesty and self-denial. These public displays of the patriarchy are gendered and gendering, repressive and repressing. Natalia's fear of approaching her father about her education, Gertru abandoning her studies for marriage, and Julia's confinement in the provincial city despite her boyfriend's invitations to live in Madrid are strong examples of such public transcripts. Limits to their self-expression and agency produce the inevitability of these women's hidden transcripts that only surface in settings of intimacy, such as Yoni's attic.

Although the chica rara Natalia has a defiant personality and rebellious aspirations, her behavior in front of authority figures throughout the novel resembles the same public transcript. Natalia behaves deferentially toward her aunt, father, and teachers, in line with the standards of the city and patriarchal regime. Her defiance, no matter how strong, is left drowning in expectations of 'proper womanly conduct.' Her diary, however, is a refuge for self-expression. Natalia retreats to her diary entries, which narrate sections of the book, in a deluge of suppressed sentiments, hidden behind the lace curtains of her personal experience. Talbot analyzes that Natalia's diary entries "allow a more intimate view of Natalia and emphasize her alienation and inability to speak openly." 68 The confidential diary account in Entre visillos echoes, as Talbot remarks, Simone de Beauvoir's insight that “'in [the diary's] pages

\footnotetext{
${ }^{4}$ Collins, "Inscribing the Space of Female Identity."

${ }^{5}$ James C. Scott, Domination and the Arts of Resistance: Hidden Transcripts (New

Haven: Yale University Press, 1990), 2.

${ }^{66}$ Scott, Domination and the Arts of Resistance, xii.

${ }^{7} \mathrm{Scott}, 7$.

${ }^{68}$ Talbot, "Female Archetypes," 83.
}

is inscribed a truth hidden from relatives, comrades, teachers, a truth with which the author is enraptured in solitude." ${ }^{69}$ Women like Natalia, then, are left alone with their thoughts and feelings, abandoned by dehumanizing moral codes. If diary entries serve as intimate self-reflections of personal struggles with society, never to be seen, then they represent the internal hidden transcript.

Talbot's reflection on the diary as a medium for voicing suppressed sentiments, however, fails to address how the defiant hidden transcripts become public. The analysis assumes that all dissent among the women in the novel is hidden in the private pages of diaries, never to be openly performed as direct opposition to power. Furthermore, Natalia's diary does not account for how or why her sisters and friends, often portrayed as paragons of the submissive female paradigm, openly express defiant hidden transcripts at the studio party. For this reason, I contend that the studio scene is a pivotal moment in the novel that opens the door for questioning the status quo. Only the private, bohemian party in the studio grants this discord.

While the theories of Bakhtin and de Certeau applied in this paper reflect upon the subversion of norms and tactical resistance in the liminal anomie which both men and women experience at the studio party, Scott's theories provide a better understanding as to how and why the young women at Yoni's studio outwardly express their normally veiled indignation toward the patriarchy. Throughout this piece, I will highlight some of these offstage, unmasked expressions that women materialize in the carnivalesque space. The experimentation in Yoni's studio begets the impetus for the young women to outwardly perform and embody their suppressed resentment of the dominant-subordinate power dynamics in Francoist Spain. These hidden transcripts translate to the public sphere when the divergent ways of being, thinking, and imagining gender roles and social norms, developed in the studio party, influence the personal decisions the young women make at the end of the novel.

\section{THE CARNIVALESQUE STUDIO}

Young women in Entre visillos traverse places of recreation outside of the home, the church, and the school. These places include the Casino, the city streets, shops, cafés, movie theaters, and bullfights. Previous literature on the gendered symbolism of public places in Entre visillos asserts that such spaces are delineated as modest venues for matchmaking. Bellver posits that "gender differences and boundaries are redrawn in situations in which men and women occupy the same general space" in a way that perpetuates the stasis of traditional norms: women remain marginalized to their 'place' in a physical room and society more broadly, male domination of social interactions and the physical atmosphere thrives, and social stratification burgeons. ${ }^{70}$ Although the sanctioned spatial layouts of gender in both the novel and Spanish society hold true in the studio, I argue that women take a distinct agentive role in intercourse and self-imagination. While Bellver contends that different settings in the novel "prove to be merely a change in scenery for the same small talk, gossip, and discussions about boyfriends," 71 I propose that new behaviors and ideas arise at the studio party. The tall structure of the Gran Hotel and the privacy of the apartment symbolically oppose the provincial city's cathedral and the Casino balcony, fostering a refuge for divergent conduct and belief. If self-awareness poses a threat to the status quo, then women's self-realization in the studio proves the space to be carnivalesque and menacing to Francoist Spain.

\footnotetext{
${ }^{9}$ Simone de Beauvoir, The Second Sex, trans. H. M. Parshley (1952; rpt. New York: Vintage Books, 1974), 380.

${ }^{70}$ Bellver, "Gendered Spaces," 40.

${ }^{71}$ Bellver, 40.
} 
In Problems of Dostoevsky's Poetics, Bakhtin outlines the characteristics of carnivalesque literature that translate to the carnivalesque studio in Entre visillos. These characteristics emphasize chaos, the inversion of norms, and the imagination of alternative social identities. The studio party celebrating the departure of Colette, a French lady who stayed at the Gran Hotel, is Spanish society upside-down, a carnivalesque space of resistance.

According to Bakhtin, carnival is a pageant in which exists "free and familiar contact among people." ${ }^{2}$ In carnival, hierarchical structures crumble, deference is demolished, and etiquette falters. In the studio, all of the party-goers actively and communally participate in the act of carnival. When Julia and Mercedes arrive at the studio party, still before sundown, "había...mucho jaleo."73 Every character present in the small room carouses carelessly, Federico drinks more than seven glasses, and the attendees all dance in pairs. ${ }^{74}$ The chimney blazes, intensifying the steamy and lascivious atmosphere of the swarming living room. Remnants of this debauchery decorate the floor: "estaba...ceniceros y botellas esparcidos por la alfombra." 75 The heat from the chimney, the sweaty bodies, and the cold from outside coalesce into fog on the shut window panes, obstructing the studio from the outside view. ${ }^{76}$ Within the private walls of the top-floor studio, protected from the rest of society's calumniating gaze and the pastoral power of the Church and the Francoist State, the characters may interact freely with one another, regardless of gendered hierarchy or sociopolitical authority. The differences between genders, ages, and blood-relations that permeate Francoist society vanish and hierarchy disintegrates, establishing a liminal anomie among the group in Yoni's attic studio. In such anomie, hidden transcripts and rebellious behaviors are welcome and manifest.

The second characteristic of the carnivalesque is "[the] new mode of interrelationship between individuals" that forms in Carnival. ${ }^{77}$ That is, new behaviors and distinct relationships, free from authority, develop between the characters. These alternative relationships, along with novel social identities, are exemplified in the couples' behavior during the party. The studio scene begins with a quarrel between Gertru and her fiancée Ángel in the Gran Hotel lobby. ${ }^{78}$ Their bickering highlights the strong animosity between the lovers that night. Despite their argument, the plans for the wedding, and the imminent promise of matrimony, the relationship between the two lovers degenerates during the party. Not only do they stop arguing, they also dissociate from each other. Ángel and Gertru hardly speak to one another; Ángel wants Gertru to tour the kitchen with Teresa so that he could court and win the heart of Colette, the French lady. ${ }^{79}$ Although Ángel's mendacious behaviors showcase the perpetration of patriarchy in the studio and Gertru's compliance to his demands exacerbates a public transcript of female subjugation, at the same time, Ángel's philandering with Colette promotes the acceptance of infidelity and free love at the party. While conceptions of traditional monogamy are abandoned and Ángel betrays his future wife, the characters in the scene experience a new sense of sexual liberation and garner divergent ideals and modes of interrelationship. Other party-goers in the scene echo Ángel's licentious principles. Friends at the party, for example, "no habían dejado [a Gertru] ponerse al lado de Ángel porque dijeron que novios con novios era un atraso." ${ }^{80}$ This

\footnotetext{
${ }^{2}$ Bakhtin, Problems of Dostoevsky's Poetics, 123.

${ }^{3}$ Martín Gaite, Entre visillos, 188, 190, 191

${ }^{4}$ Martín Gaite., 190-191.

${ }^{5}$ Martín Gaite., 188.

${ }^{6}$ Martín Gaite., 190

77 Bakhtin, Problems of Dostoevsky's Poetics, 123.

${ }^{78}$ Martín Gaite, Entre visillos, 197

9 Gaite., 190, 192

${ }^{80}$ Gaite., 196. Translation: "They did not let her stand beside Ángel because they said

that couples being with couples was backwards."
}

way, social principles are reversed as the group deems traditional relationships as "backwards." Therefore, settled interrelationships in the non-carnivalesque world disintegrate. The characters embody infidelity and free love as new, unorthodox values arise in Yoni's attic. In this carnivalesque space, these alternative norms stress the formation of liberal consciences, resistant to the mundane and the conservative principles of traditional marriage.

The new interrelations between people open the possibility for the expression of eccentricity, the third characteristic of the carnivalesque that "permits-in concretely sensuous form-the latent sides of human nature to reveal and express themselves." 81 Eccentricities like foreign commodities and ideas and new bodily proxemics constitute tactics of resistance to hegemonic, conservative culture. The French music, foreign films, English tobacco, and clothes from Tangiers reflect the bohemian eccentricity of Carnival. ${ }^{82}$ Such foreign products would have been banned in Spain under the autarkic regime. ${ }^{83}$ Yoni bypasses these bans, however, by having his American friend, Spencer, whom he met while living in New York, send him the latest trends and goods. Moreover, references to foreign figures throughout the studio scene, such as James Stewart, Juliette Greco, and Yves Montand, as well as the presence of foreigners like Colette and Pablo, bridge the isolated studio to the novel trends, ideas, and exotic imaginations of the outside world, transcending provincial life and national borders. In this way, Yoni's studio as a refuge for eccentricity stages a cosmopolitanism in resistance to isolated provincial lifestyles and autarkic state policies. These foreign influences incite characters to imagine themselves differently and adopt cosmopolitan identities.

The eccentricity of the studio is also reflected in new bodily proxemics (the positions of and space between human bodies) between the characters. Free love at the party allows for genders to intermingle liberally. Although this social orgy would have been shameful in the 1950s, non-carnivalesque Spain that Martín Gaite portrays, the characters seem to forget or ignore the moral lessons they learned in Catholic schooling and mass. Open relationships are accepted and encouraged in the bohemian studio. While some isolated couples dance along the dark corners of the room, others drink alcohol at the bar or on the ground. ${ }^{84}$ In the back, there is another room where other couples lay in the darkness, "las piernas sobresaliendo, y se movían, alternadas de hombres y de mujer." 85 Both men and women experiment with their sexuality as resistance to the strictures of everyday life. In these rooms, a carnal, sensuous eccentricity manifests, breaking the conservative mores of Spanish modesty and Catholic piety.

Mercedes never realizes what happens in the back room. Federico explains that this room is "por si se queda a dormir Yoni, o amigos." ${ }^{86}$ In this case, Mercedes maintains a public transcript by not questioning the conspicuous deceitfulness of the men in the normlessness of the studio. Given that many of the women involved in this love affair do not voice themselves in the scene, it can be understood that the studio is still a male-dominated space where men take advantage of the suspension of norms to indulge in exploitative behavior toward the female characters. In Carnival, men take pleasure in escaping their dull provincial lifestyles. Although Mercedes is deceived by the men's lustful scheming, other women optimize their freedoms to break out of their cloistered shells with these men. This room clearly demonstrates the debauched patriarchy

\footnotetext{
${ }^{11}$ Bakhtin, Problems of Dostoevsky's Poetics, 123

${ }^{82}$ Martín Gaite, Entre visillos, 182-183, 190.

${ }^{83}$ Gabriel Jackson, "The Franco Era in Historical Perspective," The Centennial Review

20, no. 2 (1976): 104-105

${ }^{84}$ Martín Gaite, Entre visillos, 191.

${ }^{85}$ Martín Gaite, 191.

${ }^{86}$ Martín Gaite, 191
} 
that still revolves around the carnivalesque space, but it also it is clear that compared to conservative norms of the city, the party is ripe with new, liberal social projections. Both men and women have the freedom to experience a level of independence and sexual liberation in the normless anomie. The alternative proxemics and eccentric relationships at the party break social barriers and imagine new, liberal worldviews in Spanish society. Despite the studio being a male-centered space, the carnivalesque space also provides new opportunities for women's agency.

The carnivalesque also consists of "carnivalistic mésalliances," the phenomenon of unifying diametrically opposite characteristics: "Carnival brings together, unifies, weds, and combines the sacred with the profane, the lofty with the low, the great with the insignificant, the wise with the stupid." ${ }^{87}$ In the non-carnivalesque world, the wedding of opposites would be almost impossible, but within the carnival, the absurd becomes the norm. An unlikely pair of characteristics coalesce in the case of Ramón, the tall, blond Englishman. Toward the beginning of the party, one of the guests, Manolo Torre, complains that the party would be a bore (tostón) until Ramón animated the studio by singing the bulerías. Manolo Torre tells Estrella, Ramón's wife, to convince him to sing. She crawls on the rug over to her husband. Martín Gaite provides a passive, composed portrait of Ramón: "estaba sentado inmóvil mirando al fuego. Se le encendían reflejos en el pelo con las llamas, se le volvían a borrar." ${ }^{8}$ The tranquil image of the fire reflecting against the light hue of his hair reinforces Ramón's calm and sedated state.

Once many more people arrive and others begin to leave, Ramón suddenly breaks into song. His fiery, yet comical, performance parallels the overbearing heat of the chimney by which he sings. Then, Ramón jumps up and begins to tap dance, avoiding the cigarettes, glasses, and nutshells that line the floor. Flailing his arms, shaking his entire body, Ramón deafeningly claps and shrieks bulerías "como epiléptico." ${ }^{99}$ Two unlikely characteristics unite in Ramón's parodical display. First, Ramón's English identity surprisingly intertwines with an authentic display of traditional flamenco dance. Second, Ramón's stoic personality mixes with his ardent spectacle of impassioned song and dance. The comically absurd scene seems to satirize Spanish folk dance while the unlikely wedding of characteristics establishes the carnivalistic mésalliance of the studio.

Ramón's performance of bulerías also constitutes a veiled tactic of resistance by mocking dominant culture and state policies. Despite flamenco's origins in Andalusian urban ghettos, this music of indigent Gypsies and Spaniards has appealed to the "whims and caprices" of elites since the mid-nineteenth century. ${ }^{90}$ A century later, Franco's regime began a campaign to appropriate popular entertainment as a tool to pacify social unrest. ${ }^{91}$ Flamenco in particular began to represent a national folkloric memory when Franco "popularized a generic flamenco style for national and international consumption." ${ }^{92}$ In an attempt to consolidate and maintain power, Franco politically sanctioned flamenco as the heartbeat of Spanish patriotism, and in doing so, founded popular culture's hegemony over everyday lives.

In addition to this historical perspective, it may prove to be analytically advantageous to look at the etymological root

\footnotetext{
Bakhtin, Problems of Dostoyevsky's Poetics, 123.

${ }^{88}$ Martín Gaite, Entre visillos, 193

${ }^{89}$ Martín Gaite, 196.

90 Timothy Malefyt, “'Inside’ and 'Outside' Spanish Flamenco: Gender Constructions in Andalusian Concepts of Flamenco Tradition," Anthropological Quarterly 71, no. 2 (1998): 65

${ }_{1}^{1}$ Helen Graham and Jo Labanyi, Spanish Cultural Studies: An Introduction: The Struggle for Modernity (Oxford: Oxford University Press, 1995), 3.

22 Malefyt, "'Inside' and 'Outside' Spanish Flamenco" 65
}

of "bulerías" to derive a deeper meaning to Ramón's satirical performance. The most commonly accepted origin of "bulerías," one of the most dramatic and rambunctious flamenco forms, derives from the word burlería, referring to the musical style as a song of "mockery.' ${ }^{93}$ Although it is unknown whether Martín Gaite had the etymology of the word in mind when writing this scene, it is nevertheless interesting to see how the root of the word underscores the boisterous mockery of dominant culture in Ramón's performance. Thus, the paradox of Ramón's mésalliance is a parody of Spanish culture that serves to mock folkloric Francoist Spain, deploying the dominant culture against itself to bastardize its essence. Such an outlandish performance unifies unlikely characteristics and burlesques the popular art form, critiquing Franco's strategies of institutionalizing entertainment to 'unify' the masses and quell dissent.

Mercedes and Julia both display additional cases of carnivalistic mésalliance. The carnivalesque space incites Mercedes, the stricter sister, to drink cognac and dance intimately with Federico, an act outside her ordinary role. ${ }^{94}$ Mercedes' usually conservative character is coupled with flirtatious behaviors and a party spirit. Similarly, although Julia has a boyfriend in Madrid, she dances with Luis. ${ }^{95}$ Julia's relationship status fuses with a new expression of sexuality. For this reason, the sisters' identities change: Mercedes lets loose and Julia temporarily disregards her committed relationship. These open expressions of promiscuity constitute tactics of resistance to the female archetypes these women typically represent in the literature about Entre visillos. The breakdown of these young women's general standards of behavior disassociates them from their normal roles in society, empowering them to perform a nonverbal hidden transcript of suppressed sexuality and revelry.

A final case of carnivalistic mésalliance manifests when Gertru forms a new perspective. Seventeen-year-old Gertru, who left her studies in favor of marriage, questions Ángel's authority during her conversation with Pablo Klein. Pablo Klein convinces Gertru to reconsider matriculating into school to finish her bachillerato the next year. ${ }^{96}$ The high-school-dropout reframes her perspectives and rejects both her fiancée's commands and the State's sanctions on female education and domesticity. This sudden change of mind reflects a hidden transcript of desiring a self-reliant role outside her status as a housewife that would have only been possible in the carnivalesque space. The desire to study is direct tactic of resistance as it subverts gender roles imposed by Francoism. Thus, the soirée fosters divergent thinking and contradictory identities that transcend the limited studio space in the subsequent chapters.

The interaction with Pablo incites Gertru to approach Ángel about her aspirations on the walk home from the party. "Oye, dice ese chico [Pablo] que por qué no termino el bachillerato... Estoy a tiempo de matricularme todavía," Gertru voices, avoiding eye contact by looking at Ángel in the reflection of a shop window. ${ }^{97}$ Ángel becomes defensive, arguing that they have already decided what is best for the both of them. When Gertru questions his authority, Ángel repudiates her challenge. "Pues porque no. Está dicho,” Ángel hammers, "Para casarte conmigo, no necesitas saber latín ni geometría; conque sepas ser una mujer de tu casa, basta y sobra."98 Gertru's fiancée reiterates the popular aphorism of the era, "mujer que sabe latín...no tiene marido ni tiene buen fin" (a woman who knows Latin does not have a husband nor a good ending). In

\footnotetext{
${ }^{93}$ Silvia Calado Olivo, Por bulerías: 100 años de compás flamenco (Córdoba: Editorial Almuzara, 2009), 235.

${ }^{4}$ Martín Gaite, Entre visillos, 194.

${ }^{95}$ Martín Gaite, 194.

${ }^{6}$ Martín Gaite, 199.

${ }^{7}$ Martín Gaite, 199.

${ }_{98}$ Martín Gaite, 199
} 
this case, Gertru's hidden transcript expressed in the carnivalesque space becomes public but is immediately rejected. Patriarchy prevails. When Ángel drops Gertru off at her home, he walks back to Yoni's party, most likely to continue to flirt with other women. Thus, the liberal aspirations that congeal in Gertru's mind at the studio lose their vitality once she leaves the party, demonstrating the unique space of the studio and the persistence of the town's dominant ideology.

In the last chapter of the novel, Gertru marries Ángel, signaling that the carnivalesque values of the studio fail to transcend the space. Gertru is unable to overcome the reproduction of patriarchal norms. Sitting in Gertru's room during the reception party, Natalia, Gertru's best childhood friend, cries, saddened by Gertru succumbing to her husbands' orders, replacing the books in her room with her wedding gifts. ${ }^{99}$ Gertru forfeiting her studies for a married life exemplifies how a traditional, secure married future is sometimes more appealing than the prospects of liberation in a society where 'liberated' women are further marginalized.

The last characteristic of the carnivalesque is desecration. According to Bakhtin, the carnivalesque degrades and satirizes religion and conventions. ${ }^{100}$ The ways that Ángel and Gertru behave at the party demonstrate how the values of liberated love denigrate the sacred convention of matrimony, considered to be the backbone of Francoist sociopolitical structures. Despite the remaining patriarchal culture that permeates the studio, free-thinking permits the possibility of rethinking gender. Previously in the novel, a group of men, including Federico, at the Casino comment on the role of women, qualifying them as "niñas de celofán" (cellophane girls). ${ }^{101}$ Soledad Fox posits that this snide remark reflects the dehumanization that takes place when women must conform to feminine standards in order to attract a man and marry for a secure future. Attempts to conform to a "doll-like demeanor," however, make women seem as if they were made of cellophane to the men, appearing to be "as artificial and fragile as the visillos that shield their daily existence."102 Expanding upon this interpretation, I propose that the notion of cellophane girls also reveals that these men view women as prizes wrapped in-rather than made of-cellophane that are awarded to macho men. In this way, women are dehumanized as sexual objects for a patriarchal world.

The carnivalesque attic, however, plants new understandings of gender that are contradictory to gendered norms, and these men's comments, during the regime. Following the party and on the walk home from the studio, Julia and Mercedes bicker over their romantic relationships and gendered expectations. Julia inverts the sexist remark when she yells at Mercedes, "te regalo a Federico envuelto en papel de celofán." "103 To Julia, it is not women that are prizes, but rather men. This inversion of gender norms demonstrates how the bohemian studio introduces progressive ideas in the minds of the young women that desecrate conservative gender values during the dictatorship. Again, the carnivalesque studio provided the intimate, non-hegemonic space for women to express and embody social critique. The inversion of the phrase proves to be a tactic of resistance against how both women and men are traditionally perceived. These liberal trajectories may have motivated Julia at the end of the novel to live and work in Madrid with her boyfriend, Miguel, thus embodying offstage sentiments in the public sphere. ${ }^{104}$

Finally, the carnivalesque power within the borders of the studio walls presents itself clearly in the case of Mercedes when she steps outside with Federico to talk on the balcony, leaving the anomie established at the party. Just as Carnival's debauchery must come to an end with the advent of Lent, so do the spatial boundaries of the studio walls divide the carnivalesque from the patriarchal and fascist. Outside of the private studio, Mercedes exposes herself to the power of State and societal norms, reentering the public space with its omnipresent scrutiny of the female behavior and body. Suddenly, the sentinelling "ojo gigantesco" of the cathedral spire, the "the all-seeing tower of the panopticon," spots Mercedes. ${ }^{105}$ Once she realizes that the two are accidentally locked out of the studio, under the surveillance of both society and State, Mercedes becomes aware of the norms she has broken at the party. Frantic and fearful, Mercedes abruptly begins to worry about el qué dirán: "Dirán que dónde estamos," she frets. ${ }^{106}$ Bellver argues that this scene "dramatizes the associations made traditionally, for women, between exterior spaces and temptation, sin, and indecency." 107 This division of the impermissible outside and the safe haven of the private studio not only suggests Martín Gaite's creative use of space to delineate tradition and modernity, patriarchy and carnivalesque liberation, but also emphasizes the studio as a unique space protected and exempt from the mores of the traditional city.

Still locked outside of the studio, Mercedes stops drinking and insists that Federico does the same, masking herself in the face of authority once again. Federico comments to Mercedes that she is "una chica muy maternal," signifying that Mercedes has returned to her normal role as a conservative agent of order and modesty. ${ }^{108}$ Then, the cathedral bells chime the tenth hour; Mercedes realizes that her curfew is approaching and must depart. Ultimately, Mercedes and Julia, watched over by the cathedral's eye, return to their home, back to tradition.

\section{IMAGINING THE WORLD UPSIDE-DOWN}

Within Entre visillos, Yoni's studio apartment, forged out of resistance, becomes a refuge for free thought and self-expression that challenges the patriarchal and state power materialized in the towering structures of the cathedral campanile and Casino balcony. While the altitude of the studio symbolically threatens higher power, the privacy of the space allows the characters to do as they please, devolving their sphere into a social milieu of anomie. The protection provided at the bohemian party offers a safe haven for manifesting hidden transcripts and employing popular tactics to both escape the oppressive regime and threaten authority. The characters' paradoxical interpersonal relationships, progressive values, and parodical behaviors constitute meaningful threats to state institutions and societal values, forging a carnivalesque space for imagining novel social identities. In carnival, men escape the banality of provincial life while young women, who otherwise confine themselves to archetypal femininity, resist the norms that hegemonic, Francoist society imposed. This is the world upside-down that incites characters to explore new life trajectories.

It is this pivotal scene that influences these women to think differently about their role in society. The cases of Gertru and Julia reflect the carnivalesque studio's powerful influence on the young women's vision of themselves and their social roles. While Gertru attempts to break the norm by finishing her degree, she ultimately surrenders to her husband's vehement denunciations. On the contrary, Julia successfully goes against the grain, leaving her family and provincial city for progressive fantasies in the capital city. These distinct experiences after the party reflect both the possibility of and

\footnotetext{
${ }^{105}$ Gagliardi, "Determined, Detached and Drowning," 433.

${ }^{106}$ Martín Gaite, 197. Translation: "They will say where we are."

${ }^{07}$ Bellver, "Gendered Spaces,” 39.

${ }^{08}$ Martín Gaite, Entre visillos, 197
} 
limitations to women's agency under hegemonic social norms during the dictatorship. Although Bellver determines that all attempts of transcending the suffocating marginalization of the authoritarian society are "inevitably thwarted," 109 particularly because most of the women end up "tied to an overbearing husband," 110 I retort that Julia maintains the negative agency of navigating predetermined social structures for her own minute personal gain. The carnivalesque studio opened Julia's eyes to a feasible escape to a bohemian lifestyle in the capital city with Miguel.

On a greater scale, outside of the claustrophobic studio and ludicrous party, Entre visillos resembles carnivalesque literature as it reflects on the limitations, emptiness, and repression of women under Franco. Seemingly benign and mundane, this critical yet realistic novel escaped the grasp of stifling 1950s Spanish censorship. A closer look, however, reveals how Martín Gaite skillfully addresses taboo and illegal topics such as fascination for foreign cultures and ways of life, gender roles, sexuality, and State and societal repression. Overall, the novel emphasizes the lives of women who break norms. Martín Gaite covertly challenges the legitimacy of social institutions and Francoist politics through the characters' behavior during and proceeding Yoni's soirée. When veiled indignation becomes public and embodied, power institutions are threatened. By way of these taboo topics, novel for the era, Martín Gaite imagines Spain as a society in which women have agency to challenge the patriarchal regime. The carnivalesque novel erases hierarchy, inverts norms, and establishes new potential Spanish identities that critique and challenge Francoism. In doing so, Entre visillos unshackles itself from the oppressive ideologies that permeated Spain under Franco's dictatorship and opens a new trajectory for reimaging Spanish society with hopes for liberation.

\section{ACKNOWLEDGEMENTS}

I would like to express my very great appreciation to the faculty of the Department of Spanish and Portuguese and the Department of Anthropology at Indiana University. I am particularly grateful to Professor Reyes Vila-Belda (Ph.D.) of the Department of Spanish and Portuguese for exposing me to the breadth of modern Spanish literature and literary criticism, including the focus of this paper, Carmen Martín Gaite's Entre visillos. I am incredibly appreciative of her invaluable insights, thoughtful guidance, and constructive revisions through the many stages of this essay, from its original Spanish form, to the paper presented at the Diálogos Graduate Student Conference 2019 at Indiana University, and to this final edition. I also wish to acknowledge Professor Jane E. Goodman (Ph.D.) of the Department of Anthropology for introducing me to many of the social theories I apply in this paper; her insightful direction has undoubtedly helped me define my academic interests and trajectories. I extend my special thanks to these professors for their support and the Indiana University Journal of Undergraduate Research for providing me the opportunity to publish this work.

\section{AUTHOR INFORMATION}

All correspondence should be sent to the first author:

stuartsones22@gmail.com

\section{BIBLIOGRAPHY}

Bakhtin, Mikhail M. Problems of Dostoevsky's Poetics. Translated by Caryl Emerson. Minneapolis: University of Minnesota Press, 1984.

\footnotetext{
${ }^{09}$ Martín Gaite, 34.

${ }_{110}$ Martín Gaite, 47.
}

Bellver, Catherine G. "Gendered Spaces: Boundaries and Border Crossings in Entre visillos.” In Carmen Martín Gaite: El cuento de nunca acabar/Never-ending Story: (apuntes sobre la narración, el amor, y la mentira), edited by Kathleen M. Glenn and Lissette Rolón-Collazo, 33-49. Boulder: Society of Spanish and Spanish-American Studies, 2003.

Bourdieu, Pierre. Outline of a Theory of Practice. Cambridge: Cambridge University Press, 1977.

Bourdieu, Pierre and Loïc J. D. Wacquant. An Invitation to Reflexive Sociology. Cambridge: Polity Press, 1992.

Calado Olivo, Silvia. Por bulerías: 100 años de compás flamenco. Córdoba: Editorial Almuzara, 2009.

Collins, Marsha S. "Inscribing the Space of Female Identity in Carmen Martín Gaite's Entre visillos.” Symposium 51, no. 2 (1997): 66-78.

Cruz-Cámara, Nuria. “'Chicas raras’ en dos novelas de Carmen Martín Gaite y Carmen Laforet.” Hispanófila, no. 139 (2003): 97-110.

De Beauvoir, Simone. The Second Sex. Translated by Howard M. Parshley. New York: Bantam Books, 1952. Reprint, New York: Vintage Books, 1974.

De Busser, Cathelijne. "Church-state Relations in Spain: Variations on a National-Catholic Theme?” GeoJournal 67, no. 4 (2006): 283-94.

De Certeau, Michel. The Practice of Everyday Life. Translated by Steven Rendall. Berkeley: University of California Press, 1984.

Foucault, Michel. Discipline \& Punish: The Birth of the Prison. Translated by Alan Sheridan. New York: Vintage Books, 1995.

Foucault, Michel. "Governmentality.” In Michel Foucault, Power, edited by James Faubion, 201-222. New York: New Press, 2000.

Fox, Soledad. "Cellophane Girls: Feminine Models in Entre visillos and Usos amorosos de la postguerra española." In Approaches to teaching the works of Carmen Martín Gaite, edited by Joan L. Brown. New York: The Modern Language Association of America, 2013.

Gagliardi, Tiffany D. "Determined, Detached and Drowning: The Use of Rhetoric of Enclosure in Carmen Martín Gaite's Entre visillos." Letras Peninsulares 16, no. 3 (2003): 431-443.

García Lorca, Federico, Allen Josephs, and Juan Caballero. La Casa De Bernarda Alba. 24th ed. Madrid: Cátedra, 1997.

Graham, Helen. "Gender and the State: Women in the 1940s," in Spanish Cultural Studies: An Introduction: The Struggle for Modernity, edited by Helen Graham and Jo Labanyi, 182-196. Oxford: Oxford University Press, 1995. 
Graham, Helen and Jo Labanyi. Spanish Cultural Studies: An Introduction: The Struggle for Modernity. Oxford: Oxford University Press, 1995.

Goffman, Erving. The Presentation of Self in Everyday Life. New York: Doubleday, 1959.

Jackson, Gabriel. "The Franco Era in Historical Perspective." The Centennial Review 20, no. 2 (1976): 103-27.

Khosravi, Shahram. Young and Defiant in Tehran. Pennsylvania: University of Pennsylvania Press, 2008.

Malefyt, Timothy Dewaal. “'Inside’ and 'Outside' Spanish Flamenco: Gender Constructions in Andalusian Concepts of Flamenco Tradition.” Anthropological Quarterly 71, no. 2 (1998): 63-73.

Martín Gaite, Carmen. Desde la ventana. Madrid: Espasa Calpe, 1999.

Martín Gaite, Carmen. Entre visillos. Barcelona: Austral, 2012.

Ochoa, Debra J. "Martín Gaite’s Visión de Nueva York: Collages of Public and Private Space." In Beyond the Back Room: Perspectives on Carmen Martín Gaite, edited by Marian Womack and Jennifer Wood, 81-98. Oxford: Peter Lang, 2011.

Scott, James C. Domination and the Arts of Resistance: Hidden Transcripts. New Haven: Yale University Press, 1990.

Talbot, Lynn K. „Female Archetypes in Carmen Martín Gaite's Entre visillos.” Anales de La Literatura Española Contemporánea 12, no. 1/2 (1987): 79-94. 